$6-2018$

\title{
The Gardening States: Comparing State Repression of Ethnic Minorities in the Soviet Union and Turkey, 1908-1945
}

Duco Heijs

Utrecht University

Follow this and additional works at: https://digitalcommons.usf.edu/gsp

\section{Recommended Citation}

Heijs, Duco (2018) "The Gardening States: Comparing State Repression of Ethnic Minorities in the Soviet Union and Turkey, 1908-1945," Genocide Studies and Prevention: An International Journal: Vol. 12: Iss. 1: 63-79.

DOI:

https://doi.org/10.5038/1911-9933.12.1.1579

Available at: https://digitalcommons.usf.edu/gsp/vol12/iss1/7

This Articles is brought to you for free and open access by the Open Access Journals at Digital Commons @ University of South Florida. It has been accepted for inclusion in Genocide Studies and Prevention: An International Journal by an authorized editor of Digital Commons @ University of South Florida. For more information, please contact digitalcommons@usf.edu. 


\section{The Gardening States: Comparing State Repression of Ethnic Minorities in the Soviet Union and Turkey, 1908-1945}

\section{Acknowledgements}

This article is an abridged version of the master's thesis I wrote at Utrecht University. The full version is available upon request. My sincere gratitude goes to Dr. Uğur Ümit Üngör for his supervision during the writing of my master's thesis and this article. 


\title{
The Gardening States: Comparing State Repression of Ethnic Minorities in the Soviet Union and Turkey, 1908-1945
}

\author{
Duco Heijs \\ Utrecht University \\ Utrecht, The Netherlands
}

\begin{abstract}
He said it was important to get to know the East/
Said the people are a garden and we are gardeners/

Trees are not rejuvenated by grafting only/

First it is necessary to trim the tree

-Poem by Ziya Gökalp, in The Red Apple, $1914^{1}$
\end{abstract}

Our Children blossom on the living trunk of our life; they are not a bouquet, they are a wonderful apple orchard. And this orchard is ours... Be so kind as to take on this job: dig, water, get rid of caterpillars, prune out the dead branches. Remember the words of the great gardener, Stalin.

-Anton Makarenko, A Book for Parents, $1937^{2}$

\section{Introduction}

Gökalp and Makarenko were agents of a "gardening" mentality that held sway in (Ottoman) Turkey and the Soviet Union in the first half of the twentieth century. In these countries, the social and ethnic realms of the state were reconceptualized as entities that required continuous cultivation in pursuit of a utopian vision of the future. This was manifested in state-sponsored interventionist programs favoring particular population groups, whilst other groups came to be regarded as unwanted, undesirable, or in another way unfit to be a part of the new order. Such unfit groups, or the "weeds" of society, were in many instances ethnic minority groups. As a result, in roughly the same time period, the Turkish and Soviet states deported, resettled, and in some instances even massacred, entire categories of their own populations on the basis of their perceived ethnic identity.

Examples of instances of state violence toward ethnic minorities in the first half of the twentieth century are abundant. In the Ottoman Empire/Turkey: the Armenian Genocide; ethnic cleansing of Greeks and Armenians during the War of Liberation; a population transfer with Greece in 1923; and deportations of Kurds from Eastern to Western Anatolia from the 1920s until the 1940s. In Tsarist Russia/the Soviet Union, examples include massive deportation campaigns during the First World War; decossackization campaigns during the Civil War; the deportation of Germans and Poles to spetsposelenie (special settlements) in 1935-1936; the various national operations of the Great Terror; and the deportation of a whole range of nationalities during and after the Second World War. ${ }^{3}$

This article compares such state repression of ethnic minority groups in the Soviet Union and (Ottoman) Turkey as instances of demographic engineering, which is in turn seen as an aspect of state-led modernization and group-based population policy. The article argues that, in pursuit of very different politico-ideological ends, these states exhibited a large degree of similarities in the ways they portrayed ethnic diversity in relation to the build-up of a new political order, as well as in the political techniques they used to repress ethnic minority groups in practice.

Comparing State Repression of Ethnic Minority Groups: Population Policy and Demographic Engineering

In recent historiography on the Soviet Union and (Ottoman) Turkey, scholars have applied the concepts of population policy and demographic engineering (as an aspect of state-led political modernization) as explanatory factors for the mass violence that was deployed towards specific

${ }^{1}$ Uğur Ümit Üngör, The Making of Modern Turkey: Nation and State in Eastern Anatolia, 1913-1950 (Oxford: Oxford University Press, 2012), 35.

${ }^{2}$ David Hoffman, Cultivating the Masses: Modern State Practices and Soviet Socialism, 1914-1939 (Ithaca: Cornell University Press, 2011), 1.

${ }^{3}$ It should be noted that whereas state violence in Turkey was aimed primarily at non-Turkish citizens, in the Soviet Union it was by all means not exclusively aimed at ethnic minority groups. Underlying the comparison of this article is the notion that the repression of ethnic minorities in the Soviet Union was a distinctive category of repression worthy of separate analysis. 
categories of people identified by the state. ${ }^{4}$ The term population policy (often used interchangeably with demographic engineering), refers in the broadest sense to these actions, techniques, or programs adopted by the state that have the purpose of influencing demographic processes. ${ }^{5}$ The methods by which states may attempt to achieve this include pronatalist policies, forced population movements, assimilation, and boundary alterations. ${ }^{6}$ Scholars implicitly or explicitly distinguish between practices of hard engineering (forced population movements or the physical destruction of population groups) and soft engineering (more subtle and indirect policies, such as incentives to migrate or birth rate limitations). ${ }^{7}$

From a historical perspective, the emergence of population policy refers to a process originating in western Europe, in which the population was reconceptualized as a social entity to be rationally studied and managed by the state, stimulating a new ethos of social state intervention. ${ }^{8}$ In nineteenth century Europe, this process became connected to a growing scientific discourse on eugenics. Advocates of eugenics argued that scientists could have a central role in improving the biological condition of human beings through cultivating elements considered desirable, whilst exterminating those considered unsuitable. ${ }^{9}$

In his monumental study on modernity and the Holocaust, Zygmunt Bauman refers to the process of state intervention with the aim of creating a perfect society as social engineering or gardening..$^{10}$ It was this vision of society as an object of administration, and a collection of problems to be solved with the institutions of the modern state, that could, according to Bauman, make "Holocaust-style solutions not only possible, but eminently 'reasonable."'11 Moreover, in several instances of genocide, the imagination of a homogeneous society in ethnic, racial, cultural, or political terms played a major role. This proved to be a particularly deadly combination when it came to be connected to mass-based revolutionary movements that saw the state as the critical agent of societal transformation. ${ }^{12}$

Despite the strong comparative outlook entailed in the concept of population policy and its successful application in the historiographies of both Turkey and the Soviet Union, the similarities

${ }^{4}$ For the Soviet Union, see, among others Peter Holquist, “State Violence as Technique: The Logic of Violence in Soviet Totalitarianism," in Stalinism: The Essential Readings, ed. David L. Hoffmann (Oxford: Blackwell Publishers, Ltd., 2003), 129-156; David Hoffmann and Yanni Kotsonis, eds., Russian Modernity: Politics, Knowledge, Practices (New York: St. Martin's Press, 2000); Hoffmann, Cultivating the Masses; Stephen Kotkin, "Modern Times: The Soviet Union and the Interwar Conjuncture," Kritika: Explorations in Russian and Eurasian History 2, no. 1 (2008), 111-164; Amir Weiner, "Nature, Nurture, and Memory in a Socialist Utopia: Delineating the Soviet Socio-Ethnic Body in the Age of Socialism," The American Historical Review 104, no. 4 (1999), 11141155; Amir Weiner, "Introduction: Landscaping the Human Garden," in Landscaping the Human Garden: Twentieth-Century Population Management in a Comparative Framework (Stanford: Stanford University Press, 2003); Uğur Ümit Üngör, "Seeing like a Nation-State: Young Turk Social Engineering in Eastern Turkey, 191350," Journal of Genocide Research 10, no. 1 (2008), 15-39; Üngör, The Making of Modern Turkey; Taner Akçam, The Young Turks' Crime Against Humanity: The Armenian Genocide and Ethnic Cleansing in the Ottoman Empire (Princeton: Princeton University Press, 2012); Nesim Şeker, "Demographic Engineering in the Late Ottoman Empire and the Armenians," Middle Eastern Studies 43, no. 3 (May 1, 2007), 461-474.

${ }^{5}$ Paul Demeny, "Population Policy: The Role of National Governments," Population and Development Review 1, no. 1 (1975), 147.

${ }^{6}$ Milica Zarkovic Bookman, The Demographic Struggle for Power: The Political Economy of Demographic Engineering in the Modern World (London: Routledge, 2013), 3.

${ }^{7}$ Morland, Demographic Engineering, chap. 2.

${ }^{8}$ Holquist, State Violence as Technique, 111-112; See also Michel Foucault, "Governmentality," in The Foucault Effect: Studies in Governmentality, ed. Graham Burchell, et al (Chicago: The University of Chicago Press, 1991), 87-104.

${ }^{9}$ Maria Sophia Quine, Population Politics in Twentieth-Century Europe: Fascist Dictatorships and Liberal Democracies (New York: Routledge, 1996), 1-15; For eugenic discourse in the Soviet Union and Turkey, see Nikolai Krementsov, "From 'Beastly Philosophy' to Medical Genetics: Eugenics in Russia and the Soviet Union," Annals of Science 68, no. 1 (2011), 61-92; Ayça Alemdaroğlu, "Politics of the Body and Eugenic Discourse in Early Republican Turkey," Body \& Society 11, no. 3 (2005), 61-76.

${ }^{10}$ Zygmunt Bauman, Modernity and the Holocaust (Ithaca: Cornell University Press, 1991).

${ }^{11}$ Ibid., 18.

${ }^{12}$ Eric D. Weitz, "Utopian Ideologies as Motives for Genocide," in Encyclopedia for Genocide and Crimes Against Humanity, ed. Dinah L. Shelton, World History in Context (Detroit: Thomson/Gale, 2005), 1124-1127. 
and differences of the mechanisms of state violence and repression of ethnic minorities in the Soviet Union and Republican Turkey is an under-researched theme. Studies that place the Soviet Union in a comparative context, for example, limit the comparison to Western Europe, or more traditionally compare it under the denominator of totalitarianism with Nazi Germany. ${ }^{13}$ A number of case studies of separate instances of ethnic cleansing and genocidal violence that include both Turkish and Soviet cases do exist, but they do not take into account the larger structure of the regime, the variation of cases among different ethnic groups, the development of policy over a longer period, or the concept of population policy. ${ }^{14}$ Part of this disposition derives from a persistent tendency to stress the exceptionality of a particular instance of state violence, such as the Great Terror in the Soviet Union, or the Armenian Genocide in Ottoman Turkey. ${ }^{15}$

In the few studies that do explicitly compare the political regimes of the Soviet Union and Turkey, the latter often comes off with a cleaner image. For example, Shmuel Eisenstadt, in comparing the Kemalist revolution with among others the Russian ones, concludes that the institutionalization of coercion was limited in Turkey. ${ }^{16}$ Stefan Plaggenborg, similarly, comparing the levels of violence in Soviet Communism, Italian Fascism, and Kemalism in Turkey, argued that the latter was the least violent of the three because, quite simply, the Kemalists killed fewer people and had a "sensibility for law and justice." 17 There are a number of issues with such an interpretation. First, Turkey simply had a much smaller population (162 vs. 16 million in 1935/1937), meaning that statements about the lower number of victims need to be qualified. Second, the fact that the number of victims was comparatively lower in Turkey should not lead us to ignore its manifold violent aspects. Third, the history of the repression of Kurdish rebellions and deportations of Kurds remains somewhat neglected, and the historiography on it is comparatively much less developed than historiography on ethnic repression in the Soviet Union.

The remaining pages of this article attempt to formulate a way to confront this historiographic gap by discussing the similarities and differences of three interrelated aspects of state repression of ethnic minority groups in Turkey and the Soviet Union. First, it looks at the way practices of state repression and forced population settlements emerged and were institutionalized by the state in the context of regime change during and after the First World War. Then, it goes on to discuss the political strategies for dealing with ethnic diversity that were formulated by political leaders in the new regimes in the first decades after their establishment, demonstrating how alternating tendencies of inclusion and exclusion were present in these policies. The final part of the article compares deportations and massacres that were deployed towards the Chechen-Ingush in the Soviet Union, and towards the Zaza Kurds in Republican Turkey. The conclusion will discuss the implications of the similarities and differences between these two cases for our understanding of demographic engineering as a method of statecraft.

\section{Regime Change}

The Republic of Turkey and the Soviet Union shared several similar historical legacies and displayed a number of common characteristics in the first decades of their formation and existence.

\footnotetext{
${ }^{13}$ Michael Geyer and Sheila Fitzpatrick, eds., Beyond Totalitarianism: Stalinism and Nazism Compared (New York: Cambridge University Press, 2009).

${ }^{14}$ Examples are Eric D. Weitz, A Century of Genocide: Utopias of Race and Nation (Princeton: Princeton University Press, 2015), which includes a short section on the Armenian genocide, and a chapter on Bolshevik violence; Naimark, Fires of Hatred, which includes case studies on ethnic cleansing of Armenians and Greeks in Anatolia and the Chechen-Ingush in the Soviet Union; and Michael Mann, The Dark Side of Democracy: Explaining Ethnic Cleansing (New York: Cambridge University Press, 2005), which offers extensive typologies of ethnic cleansing, discussing a plethora of case studies including the Armenian genocide and Communist ethnic cleansing in the Soviet Union, China, and Cambodia.

${ }^{15}$ Uğur Ümit Üngör, "State Violence under Kemalism and Stalinism: Common Themes and Analogies" (unpublished article, 2017), 9-10.

${ }^{16}$ Shmuel Eisenstadt, "The Kemalist Revolution in Comparative Perspective," in Atatürk, Founder of a Modern State, ed. Ergun Özbudun and Ali Kazancigil (London: C. Hurst, 1981), 127-140.

${ }^{17}$ Stefan Plaggenborg, Ordnung Und Gewalt: Kemalismus - Faschismus - Sozialismus (München: Oldenbourg, 2012), 258.
} 
Both states emerged on the geopolitical landscape of Europe out of the collapse of the imperial order on the continent during the First World War and its immediate aftermath. In both states, the violent epoch of the First World War was extended and spilled into new conflicts. In the Soviet Union, the First World War was followed by the Civil War that ended in 1922 with the official establishment of the Union of Soviet Socialist Republics (USSR). In the Ottoman Empire, the First World War was preceded by the Balkan Wars of 1912-1913 and followed by the War of Liberation of 1919-1923, ending with the establishment of the Republic of Turkey. The ruling parties of these successor states (respectively the Committee of Union and Progress or CUP, and its successor the Republican People's Party or RPP in the Ottoman Empire/Turkey, and the Communist/Bolshevik Party in Tsarist Russia/The Soviet Union) seized and consolidated power in this period of conflict. This had a profound impact on the ruling style of these parties, in which war and politics came to be entwined..$^{18}$ After they consolidated their power, these parties embarked upon an ambitious agenda of state-led modernization, promising definitive and radical solutions to the problems that had haunted the late imperial era. Doing so, they both preached social and cultural revolution that was to unfold under their single-party leadership. To this end, they pursued mass mobilization, political centralization, and nation building. ${ }^{19}$

Of course, there were important differences in the process of regime change as well. Most notably, the CUP came to power in the context of severe territorial loss, as a movement that wanted to radically reform, but ultimately preserve the state. What bonded them was not so much a coherent and clear-cult ideological program or doctrine that purported to fundamentally transform society or overthrow the old order, but rather their distinctive approach to uplifting their country from its current predicament. This approach was aimed at establishing an ethnically homogeneous Turkish fatherland (vatan). There were moreover strong continuities between the Kemalists of the RPP and the Young Turks of the CUP, despite the strong anti-imperial sentiment that held sway by the time the Republic of Turkey was established. The experiences of the Republic's new president, Mustafa Kemal, had been shaped as an activist in the Young Turk movement, and many of the social engineers that worked for the Young Turks before and during the War continued to do so for Kemal's Republican Party. ${ }^{20}$ The Bolsheviks, on the other hand, had come to power as a radical political party that did not want to reform the tsarist state, but abolish it and replace it entirely. They stood in the tradition of a radical revolutionary movement dating back to the nineteenth century that had lamented what they perceived as Russia's backwardness, and preached the need for it to catch up with the West through far-reaching social renovation and refashioning of the empire. Unlike the Young Turks and the Kemalists, the Bolsheviks did not want to establish a nation state, but preached class struggle and the imminent coming of socialist paradise on earth under the leadership of a strong, united vanguard party. ${ }^{21}$

As a result of these differences, the institutional continuities were far greater in the Ottoman Empire/Turkey than in Tsarist Russia/the Soviet Union. In Republican Turkey, there was only limited upheaval in the realm of political institutions, the civic bureaucracy, and the military. Bureaucratic purges and show trials were organized, but fairly limited in scope. The most significant innovation of the Kemalists was the prominence of the Republican People's Party (RPP). The RPP was increasingly used as an instrument of mass mobilization, although the implementation of politics was left to the regular state apparatus. ${ }^{22}$ In the Soviet Union, the Bolsheviks embarked directly

\footnotetext{
${ }_{18}$ Üngör, State Violence under Kemalism and Stalinism, 5.

${ }^{19}$ Ibid; Adeeb Khalid, "Backwardness and the Quest for Civilization: Early Soviet Central Asia in Comparative Perspective," Slavic Review 65, no. 2 (2006), 231-251.

${ }^{20}$ Erik Jan Zürcher and Touraj Atabaki, "Introduction," in Men of Order: Authoritarian Modernisation in Turkey and Iran, 1918-1942 (London: I.B.Tauris, 2004), 1-12; Ryan Gingeras, Fall of the Sultanate: The Great War and the End of the Ottoman Empire, 1908-1922 (Oxford: Oxford University Press, 2016), 1-7; M. Şükrü Hanioğlu, Atatürk: An Intellectual Biography (Princeton: Princeton University Press, 2011), 48; Üngör, The Making of Modern Turkey, 121.

${ }^{21}$ Hoffmann, Cultivating the Masses, 1-16; Yinghong Cheng, Creating the "New Man": From Enlightenment Ideals to Socialist Realities (Honolulu: University of Hawaii Press, 2009), 15-20.

${ }^{22}$ Erik Jan Zürcher, "Institution Building in the Kemalist Republic: The Role of the People's Party," in Men of Order: Authoritarian Modernisation in Turkey and Iran, 1918-1942, ed. Erik Jan Zürcher and Touraj Atabaki (London: I.B.Tauris, 2004), 98-112.
} 
after the revolution upon a process of immense party-based institutionalization and an almost complete restructuring of the relationship between state and society. This leadership strategy had an enormous impact on the shape and structure of the state and its bureaucracy, in which state and party increasingly overlapped. ${ }^{23}$ This immense institutional upheaval also led to large-scale repression of the newly established institutions themselves, and bureaucratic purges and show trials run throughout the history of the Bolshevik party. ${ }^{24}$

Whatever their differences, the processes by which the successor states were established and regime change was accomplished involved large-scale population policies and repression of ethnic minorities. In Russia, the practice of violently excising certain populations considered dangerous or harmful bridged the revolutionary divide and was practiced by both the Tsarist and Soviet regimes (and, for that matter, by the Provisional Government in 1917 as well). ${ }^{25}$ Early twentieth century Russian political leaders were convinced they had a civilizing mission, in which order would be brought to the culturally backward non-Russians. ${ }^{26}$ An important part of this process was the classification of the population into a simple hierarchy of nationalities that was ranked according to degrees of reliability. ${ }^{27}$ In the context of total mobilization for the First World War, military authorities argued that certain historically sensitive border regions had to be cleansed from populations they considered unreliable. ${ }^{28}$ During the war, the Russian government deported up to one million non-Russian subjects, mostly Jews and Germans, in one of the largest practices of forced migration up to the Second World War. ${ }^{29}$ During the Civil War that followed the revolution, all warring parties practiced the deportation of certain distrusted elements of the population. In the words of one Soviet official speaking about the policy of decossackization, the objective of establishing Soviet power was unthinkable "until we slaughter all [the Cossacks] and resettle the Don with an external element." 30

In the Ottoman Empire, the First World War also provided the context for large-scale population policies. During the war, in 1915, Ottoman authorities decided to deport the entire Armenian population, which it had come to regard as a dangerous fifth column, from the war zone in the East to the Syrian Desert. The campaigns went far beyond deportations as thousands of Armenians were massacred outright. Recent estimates based upon extensive archival research indicate that the number of deportees lay between 850,000 and 1,200,000, of who about 600,000 had perished by 1916. ${ }^{31}$ The governor of Diyarbekir province argued that the "Armenian question" was a problem of choosing "between killing the disease and the patients or seeing the destruction of the

${ }^{23}$ Yoram Gorlizki and Hans Mommsen, "The Political (Dis)Orders of Stalinism and National Socialism," in Beyond Totalitarianism: Stalinism and Nazism Compared, ed. Michael Geyer and Sheila Fitzpatrick (New York: Cambridge University Press, 2009), 41-86.

${ }^{24}$ For a history of party purges, see J. Arch Getty and Oleg V. Naumov, The Road to Terror: Stalin and the SelfDestruction of the Bolsheviks, 1932-39, Annals of Communism (New Haven: Yale University Press, 2000); Sheila Fitzpatrick, "How the Mice Buried the Cat: Scenes from the Great Purges of 1937 in the Russian Provinces," The Russian Review 52, no. 3 (1993), 299-320.

${ }^{25}$ Peter Holquist, "To Count, to Extract, and to Exterminate: Population Statistics and Population Politics in Late Imperial and Soviet Russia," in A State of Nations: Empire and Nation-Making in the Age of Lenin and Stalin, ed. Ronald Grigor Suny and Terry Martin (New York: Oxford University Press, 2001), 111-144.

${ }^{26}$ Mark Steinberg, "Russia's Fin Die Siècle, 1900-1914," in The Cambridge History of Russia. Vol. 3, The Twentieth Century, ed. Ronald Grigor Suny (Cambridge, UK: Cambridge University Press, 2008), 89-93.

${ }^{27}$ Eric Lohr, Nationalizing the Russian Empire: The Campaign against Enemy Aliens during World War I (Cambridge, MA: Harvard University Press, 2003), 84,121-122,157, 164-165.

${ }^{28}$ Holquist, To Count, to Extract, and to Exterminate, 124.

${ }^{29}$ Eric Lohr, "The Russian Army and the Jews: Mass Deportation, Hostages, and Violence during World War I," The Russian Review 60, no. 3 (2001), 404.

${ }^{30}$ Holquist, To Count, to Extract, and to Exterminate, 129.

${ }^{31}$ For a historiographic discussion of estimates of the death toll of the Armenian Genocide, see Ronald Grigor Suny, "They Can Live in the Desert but Nowhere Else: A History of the Armenian Genocide (Princeton: Princeton University Press, 2015), 354-355; Akçam, The Young Turks' Crime Against Humanity, 258, gives a number of $1,200,000$ casualties. 
Turkish nation at the hands of madmen." ${ }^{32}$ Deportation practices during the war were not limited to the Armenian population, as Yezidis, Syriacs, and Kurds were also deported. ${ }^{33}$ Moreover, several segments of the Greek population were deported from the Aegean littoral to the hinterland of Asia Minor. Eşref Sencer Kuşçubaşı, one of the leaders of the Special Organization, the organization that was responsible for the implementation of the deportations, described Ottoman Greeks as internal tumors that had to be removed. ${ }^{34}$ Population policies aimed towards ethnic minorities were also practiced by the later Kemalist state. Already in 1907, Atatürk proposed "the Ottoman Empire should voluntarily dissolve itself in order to pave the way for population exchanges that would give rise to a Turkish nation state." ${ }^{\prime 35}$ To this end, a population exchange with Greece was organized, in which the remainder of the Greek Orthodox population (about 900,000 people) was exchanged against Muslims from Greece (about 400,000). ${ }^{36}$

\section{Governing Ethnicity, Conquering Backwardness}

These violent practices stood in stark contrast with a much-used discourse that promised the possibility that irrespective of ethnic identity; various population groups inhabiting the territory of the state could join the new political order. This chasm had much to do with the double-edged nature of the notion of backwardness that was used in both states. On the one hand, it were the states as a whole that were to catch up with the West under the auspices of a political elite that was presented as civilized and omnipotent. On the other hand, backwardness was used to refer to particular regions that were considered notoriously uncivilized and an impediment to development in general. In any case, backwardness was a discursive vehicle for implementing radically transformative policies. The possibility of overcoming regional backwardness was proclaimed in both states, and was predicated upon the espousal of nurturist and non-essentialist conceptions of nationality of political leaders.

In Turkey, the Kemalists believed that non-Turkish population groups, most importantly the Kurds, could become Turkified through a process of (forced) assimilation. The Soviet regime also made painstaking efforts to prove that irrespective of ethnic background, every population group could participate in socialist construction. This shared ideal partly derived from nurturist and nonessentialist conceptions of nationality and ethnicity that held sway in both regimes. Political leaders of the new regimes rejected biological racism and the idea that ethnic and national identities were fixed in time. According to Stalin, the nation was a political form characteristic of the capitalist period, defined as a "historically evolved, stable community of language, territory, economic life, and psychological make-up manifested in a community of culture." ${ }^{37}$ Moreover, Stalin argued, although nations may have certain particularities or distinguishing characteristics, these are not fixed or unchangeable, but are subject to changing socio-historical circumstances. ${ }^{38}$ Ziya Gökalp, an important ideologue of the Young Turk and Kemalist regimes, had similar convictions. Gökalp argued, "race is a term properly used only in zoology." ${ }^{39}$ Moreover, he argued that "social traits are not transmitted through biologic inheritance but only through education, which means that ethnic origin plays no role whatever as regards national character." ${ }^{40}$

Yet, despite such nurturist proclamations, a trend towards exclusiveness on ethnic grounds can be discerned in both states. In the Soviet Union of the 1930s, non-Russian ethnicity had become

\footnotetext{
${ }^{32}$ Erik Jan Zürcher, Turkey: A Modern History (New York: I.B. Tauris, 2004), 346, fn 20.

33 Üngör, The Making of Modern Turkey, 101.

${ }^{34}$ Zürcher, Turkey, 346, fn. 20.

${ }^{35}$ Hanioğlu, Atatürk, 37.

${ }^{36}$ Zürcher, Turkey, 164; For the population exchanges see Renee Hirschon, Crossing the Aegean: An Appraisal of the 1923 Compulsory Population Exchange between Greece and Turkey (New York: Berghahn Books, 2003).

${ }^{37}$ Joseph Stalin, "Marxism and the National Question (1913)," in Marxism and the National and Colonial Question, a Collection of Articles and Speeches, trans. A. Fineberg (Moscow: Partizdat, 1934$), 8$.

${ }^{38}$ Stalin, Marxism and the National Question, 8.

${ }^{39}$ Ziya Gökalp, The Principles of Turkism: Translated from the Turkish and Annotated by Robert Devereux, trans. Robert Devereaux (The Netherlands: Leiden E.J. Brill, 1968), 12.

${ }^{40} \mathrm{Ibid}, 13$.
} 
a marker of unreliability, and enemies of the state were increasingly defined in ethnic terms. ${ }^{41}$ This process reached its climax in the context of the Second World War with the construction of a whole range of enemy nations that were perceived as inherently subversive of Soviet rule. Leaders in the Republic of Turkey oscillated on a similar scale. Whereas in 1921 Atatürk had proclaimed the possibility of granting Kurdish groups local autonomy, only four years later he discarded any possibility of giving minority groups equal rights. ${ }^{42}$ Moreover, after several Kurdish rebellions, a picture of the Kurds was generated as being Mountain Turks that were culturally backward, incapable of giving up their tribal identity, and forming an internal threat to the territorial integrity of Turkey. ${ }^{43}$

This chasm between a nurturist discourse and an increasingly violent and exclusive political practice had much to do with a tension between, on the one hand, the strategic necessity of incorporating certain ethnic minority groups into the new order, and on the other hand, experiences of resistance to the new regimes from certain ethnic groups. As Stalin himself remarked, almost half of the Soviet population consisted of non-Russians, and they mostly inhabited border regions that "abound in raw materials, fuel and foodstuffs", but were "less developed than Central Russia" and politically and military vulnerable. ${ }^{44}$ Simultaneously, Stalin warned of the danger of "petty bourgeois elements" that could infiltrate the party, a danger that was particularly immediate in border regions. ${ }^{45}$ In Turkey, the Kurds accounted for almost twenty percent of the population and inhabited a large contiguous area in the southeast. Hence, their adherence to the new regime was deemed crucial for the maintenance of the territorial integrity of the state. Kurdish resistance to assimilationist policies of the Kemalist state were seen through the lens of regional backwardness, and Kurds were seen as "the evils of Turkey's pre-modern past." 46 The fears of both regimes were of course not entirely fabricated. In the Soviet Union, peasant resistance to the programs of forced collectivization was substantially more widespread in the border regions. ${ }^{47}$ In Turkey, of the eighteen rebellions that broke out on Turkish territory in the period of 1924-1938, Kurdish groups organized sixteen of them. ${ }^{48}$

In order to overcome such resistance and perceived backwardness, both states launched ambitious modernization programs that were aimed at forging a new identity among certain elements of the population that were considered problematic. During the 1920s and the 1930s, the Bolsheviks launched extensive campaigns of so-called indigenization or nativization (korenizatsiia). ${ }^{49}$ These campaigns stimulated the development of national institutions, national languages, and national elites. Hence, although the Soviet Union was a unified state that institutionalized nationality, it did

${ }^{41}$ Mark Levene, Crisis of Genocide: The European Rimlands 1912-1938 (Oxford: Oxford University Press, 2014), 348; Weiner, Nature, Nurture, and Memory; Eric D. Weitz, "Racial Politics without the Concept of Race: Reevaluating Soviet Ethnic and National Purges," Slavic Review 61, no. 1 (2002), 1-29; Francine Hirsch, "Race Without the Practice of Racial Politics," Slavic Review 61, no. 1 (2002), 30-43.

${ }^{42}$ Mesut Yegen, "'Prospective-Turks' or 'Pseudo-Citizens': Kurds in Turkey," The Middle East Journal 63, no. 4 (2009), 599.

${ }^{43}$ Welat Zeydanlığlu, “'The White Turkish Man's Burden': Orientalism, Kemalism and the Kurds in Turkey," in Neo-Colonial Mentalities in Contemporary Europe? Language and Discourse in the Construction of Identities, ed. Guido Rings and Anne Ife (Newcastle upon Tyne: Cambridge Scholars Publishing, 2008), 8.

${ }^{44}$ Joseph Stalin, "The October Revolution and the National Policy of the Russian Communists (1921)," in Marxism and the National and Colonial Question, a Collection of Articles and Speeches, trans. A. Fineberg (Moscow: Partizdat, 1934), 117.

${ }^{45}$ Joseph Stalin, "Theses on the Immediate Tasks of the Party in Connection with the National Problem, Presented to the Tenth Congress of the R.C.P., Endorsed by the Central Comittee," in Marxism and the National and Colonial Question, a Collection of Articles and Speeches, trans. A. Fineberg (Moscow: Partizdat, 1934), 88-98.

${ }^{46}$ Yegen, Prospective-Turks or Pseudo-Citizens, 599.

${ }^{47}$ See Lynne Viola, Peasant Rebels under Stalin: Collectivization and the Culture of Peasant Resistance (New York: Oxford University Press, 1996), 110.

${ }^{48}$ Zeydanlığlu, The White Turkish Man's Burden 8; Soner Cagaptay, Islam, Secularism and Nationalism in Modern Turkey: Who Is a Turk? (Abingdon: Routledge, 2006).

${ }^{49}$ Yuri Slezkine, “The USSR as a Communal Apartment, or How a Socialist State Promoted Ethnic Particularism," in Stalinism: New Directions (London: Routledge, 2000). 
not strive to create an overarching national identity. There was no single official language, and no single national culture, even during the return to an increasing Russian nationalist discourse in the $1930 \mathrm{~s} .{ }^{50}$ Scholars of Soviet nationality policy agree that, in principle, it was aimed at depriving nationality of its content by granting the forms of nationhood with the goal of delivering the message of the revolution in the Soviet Union's various languages. ${ }^{51}$ Thus, nationality policy was as much a way of granting non-Russian populations a degree of autonomy, as it was a means of achieving central control over the country's periphery. This is what Stalin meant to achieve with his famous formula of "national in form, socialist in content."

In Turkey, a comprehensive approach to assimilate the Kurdish population was formulated in the so-called Şark Islahat Planı (Eastern Regions Reform Plan). ${ }^{52}$ Moreover, several InspectorateGenerals were established as regional governments in areas that had witnessed some form of Kurdish resistance. The Inspectorate-Generals were meant to incorporate these regions in the Turkish nation through implementing policies realizing Turkification. ${ }^{53}$ In order to achieve the strengthening of national consciousness among the Anatolian population in general, the Kemalists launched a comprehensive program aimed at the replacement of Islam as the basis of Turkish identity with a so-called scientific theory of Turkish peoplehood. This theory was exalted in the (in)famous "Turkish History Thesis," developed in the 1930s by several leading Turkish scientists. This thesis, backed up with Darwinian social science and anthropological research, argued that the Turks stood at the cradle of all human civilizations. ${ }^{54}$ The Turkish History Thesis also involved a denial of the ethnic identity of the Kurds. The Kurds were constructed as Turks who had "forgotten their Turkishness." This perception, understood as scientific fact, became part of the Turkish state's official discourse, legitimizing a program of forced Turkification that was to "integrate the Kurds into the Turkish core." 55

Above all, these were programs aimed at creating a legible, standardized and manageable population. Cultural diversity now became a symptom of backwardness. In Soviet Central Asia, where peoples' identities were still based on their tribal or clan identities, the response was to nationalize the territories they inhabited, most notably through the formation of a standardized language. This process would establish the amalgamation of several tribes and clans into a new nation. Hence, in the Turkmen republic, the population had to be Turkmenized, in Uzbekistan, Uzbekified, etc. This search for identity was for a large part instigated from above, by Soviet scientists and anthropologists who marked certain social patterns as being characteristic of the newly established nation..$^{56}$ Yet, this policy created a whole array of contradictory and unwanted responses, such as the possibility for certain ethnic groups to wrap resistance to certain policies of the Soviet regime in the flag of newly acquired national interests. ${ }^{57}$

The practice of population resettlements was part and parcel to the establishment of national institutions and the organization of the state according to ethnic criteria. Throughout the 1920s and the 1930s, both regimes were actively involved in replacing entire categories of the population, although the way they did so and with which purposes differed significantly. In Turkey, two major Resettlement Laws were passed in 1926 and in 1934. These laws provided the legal framework for settling of Turkish immigrants into non-Turkish areas and, reversely, for the moving of segments of the Kurdish populations out of these areas and settling them into western Anatolia where they were

\footnotetext{
${ }^{50} \mathrm{Ibid}, 34$.

${ }^{51}$ For a historiographic discussion, see Ronald Grigor Suny and Terry Martin, eds., State of Nations: Empire and Nation-Making in the Age of Lenin and Stalin (New York: Oxford University Press, 2001), 3-22.

${ }^{52}$ Yeşim Bayar, Formation of the Turkish Nation-State, 1920-1938 (New York: Palgrave MacMillan, 2014), 51-52.

${ }^{53}$ Cagaptay, Islam, Secularism and Nationalism, 22, 47-48.

${ }^{54}$ Hanioğlu, Atatürk, 164-183.

${ }^{55}$ Zeydanlığlu, The White Turkish Man's Burden, 9.

${ }^{56}$ Francine Hirsch, Empire of Nations: Ethnographic Knowledge \& the Making of the Soviet Union (Ithaca: Cornell University Press, 2005), 173-174; see also Adeeb Khalid, "Nationalizing the Revolution in Central Asia: The Transformation of Jadidism, 1917-1920," in State of Nations: Empire and Nation-Making in the Age of Lenin and Stalin, ed. Ronald Grigor Suny and Terry Martin (New York: Oxford University Press, 2001), 145-164.

${ }^{57}$ See, for example, Northrop, Nationalizing Backwardness.
} 
to be "made into Turks." ${ }^{58}$ The Kurds that were deported to Western Anatolia were to be spread geographically to prevent their congregation in separate territories. This strategy, called ethnic dilution by scholars of population policy, ${ }^{59}$ was already practiced by the CUP during deportations of Kurds in the aftermath of the Armenian genocide, testifying to the degree to which strategies of population resettlement were a defining aspect of both the Young Turks and the Kemalists. ${ }^{60}$

In the Soviet Union, the strategy of preaching socialism through newly established national institutions also entailed the settling of territorially dispersed population groups into designated national territories. Thus, for example, Assyrians, Kalmyks, Jews, Roma, and Gypsies were brought together in order to form a national territory so that they could be properly treated as nationalities. ${ }^{61}$ This constructive element in the Soviet strategy of population settlement decreased in the increasingly tense international context of the 1930s, and as a response to experiences with widespread resistance against the collectivization campaigns in the borderlands. ${ }^{62}$ This gave way to a more primordial understanding of nationality in which certain ethnic or national groups were seen as being anti-Soviet or kulak by nature. ${ }^{63}$

This increasing exclusiveness on ethnic grounds did not necessary entail an abandonment of the nurturist principle, but rather a strengthening of it. It were, most of all, the ethnic and other pre-national identities that had to disappear, more so than the specific groups themselves. In the perception of the political elite, the ethnic identity of certain groups and resistance to the new order in several instances overlapped. This is even more ironic because, to a large extent, it was the regime itself which had ascribed ethnic identity through the launching of efforts to categorize the population. Importantly, in the Soviet Union ethnic identity was not the only kind of identity that could overlap with resistance to the new order, and a whole range of people of Russian ethnicity were deemed anti-Soviet by nature and fell subject to repression.

\section{Collective Punishment: The Deportation, Resettlement and Massacring of the Chechen-Ingush and the Zaza Kurds}

How were violent population policies planned and implemented, and how did they play out on the ground? Here, two instances of mass resettlement programs that were implemented in the Soviet Union and in Turkey will be compared in some detail: the resettlement of the entire Chechen-Ingush population to Central Asia, and the massacres and mass deportations of the Kurdish population in the Dersim area between September 1937 and August 1938. Two important differences between these campaigns should be marked from the outset. First, the Soviet deportation of the ChechenIngush occurred during wartime, whereas the Kemalist massacres and deportations of the Zaza Kurds occurred during peacetime. Second, the Chechen-Ingush was only one of the many nationalities that fell subject to the repressive policies of the state. ${ }^{64}$ There were also important similarities, however. Both campaigns consisted of large-scale operations that were implemented by the state with a tremendous display of military or police power, occurring within a relatively limited timespan in a well-defined geographic area. Both instances might be dubbed forced internal population movements, as they were aimed at the removal and resettlement of a specific population group within the boundaries of the state (other than ethnic cleansing, which is typically aimed at expelling the population group from the state's boundaries). Finally, both the Dersim Kurds and the Chechen-Ingush had a notable pre-history of clashes with the centralizing state. In

${ }^{58}$ Erol Ülker, "Assimilation, Security and Geographical Nationalization in Interwar Turkey: The Settlement Law of 1934," European Journal of Turkish Studies, Social Sciences on Contemporary Turkey, no. 7 (2008), 1-19; Cagaptay, Islam, Secularism and Nationalism, 86-90.

${ }^{59}$ See Bookman, The Demographic Struggle for Power, 125-127.

${ }^{60}$ Akçam, The Young Turks' Crime Against Humanity, 43-45; Üngör, Seeing like a Nation-State, 26.

${ }^{61}$ Terry Martin, The Affirmative Action Empire: Nations and Nationalism in the Soviet Union, 1923-1939 (Ithaca: Cornell University Press, 2001), 44.

${ }^{62}$ Ibid, 69, 302-8.

${ }^{63}$ Weiner, Nature, Nurture, and Memory, 1128-1129.

${ }^{64}$ For an overview, see Pavel Polian, Against Their Will: The History and Geography of Forced Migrations in the USSR (Budapest: Central European University Press, 2004), 115-181. 
both cases, entire population groups fell subject to collective punishment campaigns because they bore the same ethnicity of those who had dared to actively resist the new political order.

The Chechen and Ingush (referring to themselves as Vainakhs, or "our people") were (and remain) the largest Muslim group in the North Caucasus region. The region they inhabit consists of steppe flatlands in the north, and an isolated and mountainous south. The ChechenIngushetia ASSR was considered a backward region by the Soviets. This had much to do with the frustrations resulting from attempts to incorporate the region in the Soviet body politic. There was widespread resistance in the region to the Bolshevik Red Army during the Civil War, and armed peasant resistance to collectivization. During the 1930s, the regime suspected widespread activities of counterrevolutionary bands and with the outbreak of the Second World War the region saw a serious armed uprising. There were also clashes between the Soviet secret police (People's Commissariat for Internal Affairs; Narodnyi Komissariat Vnutrennikh Del or NKVD) and armed gangs, mostly of Chechen-Ingush nationality ${ }^{65}$ The Dersim region (current-day Tunceli) is a region in Eastern Anatolia that is surrounded by high mountains and has a harsh climate. The region was known by the Kemalist regime for its backwardness, lawlessness, and tribalism. The region was inhabited by Zaza Kurds that were organized in tribes and spoke a unique form of the Zaza language and adhered to a specific branch of Alevism. In 1920, some tribes living in the region had demanded autonomy from the newly established Turkish government. ${ }^{66}$ By the early 1930s, the government had still not managed to establish control over the region. Moreover, by that time, the Turkish minister of Interior, Şükrü Kaya had been led to believe by several reports that the region was prone to resistance, well-armed, and, worst of all, Kurdifying instead of Turkifying. ${ }^{67}$ Moreover, under the leadership of Seyit Riza, several tribes had declared their intention to resist ongoing government intervention in Dersim. If one is to believe the military reports, 22,700 people were involved in this rebellion, of who about 4,200 were armed..$^{68}$

Substantial planning preceded both cases of forced population settlement. The Second World War and the alleged collaboration of the population with the invading Nazis (even though the Chechen-Ingush ASSR avoided full-scale occupation) provided the direct context of the resettlement of the Chechen-Ingush. NKVD chief Lavrentiy Beria was responsible for the planning and organization of the operation. Preparations to resettle the entire Chechen-Ingush population started in December 1943 directly after the Red Army had driven out the German Wehrmacht from the Northern Caucasus. Planning under the leadership of Beria had lasted for about a year, whereas the operation itself was completed in only a week. Everything was thought out in advance. The sudden appearance of a high number of troops was explained as training maneuvers of the Red Army in mountainous regions. Those anti-Soviet elements that were most likely to actively resist were identified and arrested individually before the onset of the operations. Detailed intelligence on the area moreover convinced the NKVD to sweep the more easily accessible foothills and lowlands in the first three days, and then use the remaining five days to remove the people from the more difficultly accessible mountainous areas. ${ }^{69}$ To ensure effectiveness, the NKVD recruited local party leaders, clerical leaders, and other local elites to cooperate. These local authorities were sent into all the districts to announce to the population that they would be deported for having betrayed the Motherland and collaborated with the Germans. These elites were promised certain benefits during their resettlement (most notably, they were permitted to bring more personal belongings upon deportation) and were shipped off on the last

\footnotetext{
${ }^{65}$ Pohl, Ethnic Cleansing in the USSR, 82-83.

${ }^{66}$ David McDowall, A Modern History of the Kurds, (London: I.B. Tauris, 2004), 185-186.

${ }^{67}$ Nicole Watts, “Relocating Dersim: Turkish State-Building and Kurdish Resistance, 1931-1938," New Perspectives on Turkey 23 (2000), 12.

${ }^{68} \mathrm{Ibid}, \mathrm{fn} 42$.

${ }^{69}$ Beria to Stalin, “O Podgotovke Operacii po Pereseleniju Čečencev i Ingušej,” in Stalinskie Deportacii, 1928-1953, Čast' 3. Etničeskie Deportacii Periodia Velikoj Otečestvennoj Vojny (22 ijunja 1941- 9 maja 1945), ed. N.L. Pobol and P. Polian (Moscow: The Yakovlev Foundation, 2005), Dokument 3.115, accessed May 24, 2017, http://www. alexanderyakovlev.org/fond/issues-doc/1022200.
} 
day of the deportations..$^{70}$ The Soviet deportation of the Chechen-Ingush was total in intent as well as implementation. Even Chechen-Ingush residing outside the area of the Chechen-Ingush ASSR fell subject to deportation and resettlement. By February 29, 1944 a mere seven days after the start of the operation, Beria reported that 478,479 people were evicted, of whom 91,250 were Ingush and 387,229 were Chechens. ${ }^{71}$

In the case of Dersim, it is more difficult to point at a concrete plan, and operations lasted much longer. Central authorities had certainly wanted to suppress and cleanse the region in the context of their general intention to abolish both Kurdish territories and Kurdish identity as such since the late 1920s, with the formulation of the Eastern Regions Reform Plan. Placing the operations in the general context of the widely used practice of resettling Kurds, it is impossible to deny that a substantial degree of planning must have been involved, although it remains unclear how hasty the decision to actually start the operations was finally made. Operations themselves consisted of two phases. Military intervention was triggered in March 1937, with the burning down of a strategic bridge. By the spring of 1937, troops started to move in the area, arrested Riza and other activists, and hanged them several days after their capture. In the second phase starting in 1938 , a more comprehensive operation was launched. The operation was phrased as a punishment campaign that was necessary to civilize and re-educate the local population. ${ }^{72}$

Both operations were extensively professionalized and involved only very limited mobilization of the local population. Beria came to the Chechen-Ingush ASSR with an overwhelming 119,000 NKVD, NKGD, and SMERSH officers, soldiers, and operatives. ${ }^{73}$ In Dersim, about 50,000 troops were responsible for the operations. ${ }^{74}$ Relative to the population of the regions, the mobilization of armed forces was even larger in Turkey than in the Soviet Union. Yet, the massacres, deportation, and resettlement of the Zaza Kurds of Dersim was partial, unlike the total deportation of the Chechen-Ingush. The exact number of deaths and deportees in Dersim has not been established clearly. A recently found military source counts 13,160 civilian casualties and 11,818 deported out of a total population of about 65,000 to $70,000 .^{75}$

Both operations went accompanied with horrendous brutalities. The deportation of the Zaza Kurds from the Dersim area saw a far greater degree of mass murder in relative and absolute terms. During the cleansing of a forbidden zone - the core region of Dersim that was most difficult to access - the army entered the villages, marched off the local population, and left after burning down their houses and fields. A substantial part of the population was killed outright. Villagers were assembled in a central square, where they were told they would be deported, and then marched off. When outside the forbidden zone, they were tied to their hands, told to stand in a line, and shot by machine gun fire. Their bodies were burned. The part of the population that survived

${ }^{70}$ Beria to Stalin, "O Podgotovke Operacii po Pereseleniju Čečencev i Ingušej," in Stalinskie Deportacii, 1928-1953, Čast' 3. Etničeskie deportacii periodia velikoj otečestvennoj vojny (22 ijunja 1941- 9 maja 1945), ed. N.L. Pobol and P. Polian (Moscow: The Yakovlev Foundation, 2005), Dokument No. 3.116, accessed May 24, 2017, http://www. alexanderyakovlev.org/fond/issues-doc/1022200.

${ }^{71}$ Beria to Stalin, “O Zaveršenii Operacii po Vyseleniju Čečencev i Ingušej,” in Stalinskie Deportacii, 1928-1953, Čast' 3. Etničeskie Deportacii Periodia Velikoj Otečestvennoj Vojny (22 ijunja 1941- 9 maja 1945) ed. N.L. Pobol and P. Polian (Moscow: The Yakovlev Foundation, 2005), Dokument 3.121, accessed May 24, 2017, http://www. alexanderyakovlev.org/fond/issues-doc/1022221.

${ }^{72}$ Özgür Inan Boztas, “Did a Genocide Take Place in the Dersim Region of Turkey in 1938?” Papers of the Strassler Center for Holocaust and Genocide Studies (2015), 9.

${ }^{73}$ Beria to Stalin, “O Nagraždenii Učastnikov Operacii po Vuseleniju Čečencev i Ingušej,” in Stalinskie Deportacii, 1928-1953, Čast' 3. Etničeskie Deportacii Periodia Velikoj Otečestvennoj Vojny (22 ijunja 1941- 9 maja 1945) ed. N.L, Pobol and P. Polian (Moscow: The Yakovlev Foundation, 2005), Dokument 3.124, accessed May 24, 2017, http:// www.alexanderyakovlev.org/fond/issues-doc/1022225.

${ }^{74}$ McDowall, A Modern History of the Kurds, 209.

${ }^{75}$ Hans-Lukas Kieser, “Dersim Massacre, 1937-1938," Online Encyclopedia of Mass Violence, July 27, 2011, sec. C, accessed May 24, 2017, http://www.sciencespo.fr/mass-violence-war-massacre-resistance/en/document/dersimmassacre-1937-1938. The relevant source was originally published in the Turkish newspaper Radikal, November 20, 2009. The newspaper was shut down by the Turkish government in 2016, but the article was still available online at the time of writing, http://www.radikal.com.tr/turkiye/resmi-raporlarda-dersim-katliami-13-bin-kisiolduruldu-965187/. 
the cleansing of the forbidden zone was expelled and settled in more easily accessible (and as a result, more easily to control) areas of Dersim. ${ }^{76}$

Although the NKVD operations in the Chechen-Ingush ASSR were more professionalized and saw less high degrees of killing, excesses and atrocities occurred here as well. Of course, these were excesses only in the sense of a deviation from an already violent standard. The usual procedure was that people were forced into military trucks (US Studebakers provided by the Lend-Lease program ${ }^{77}$ ) at gunpoint, driven to train stations, and huddled into overcrowded train carriages like cattle. In several villages in the mountains that were difficult to access by truck, the entire civilian population was massacred. In the village of Khaybakh, an armed NKVD unit that was delayed in the mountains locked hundreds of villagers into a local barn, set it on fire, and shot those trying to escape. ${ }^{78}$ The deportees also suffered extreme hardship during their journey to Central Asia. There were many instances of typhoid during the transportation, and people that strayed more than the permitted distance from the trains, when they stopped for a break, were shot outright. ${ }^{79}$

As regards the settlement of the Zaza Kurds and the Chechen-Ingush, both state programs were accompanied with practices of ethnic dilution and forced assimilation, two key aspects of demographic engineering. Ethnic dilution can be defined as the territorial dispersion of populations in order to prevent them from organizing amongst themselves ${ }^{80}$ Territorial dispersion of Kurdish groups was a core element of Kemalist deportations of Kurds. Exiled Kurdish tribes were sent to Western Anatolia with their family, and official government policy stipulated that they were never to exceed ten per cent of the local population there. ${ }^{81}$ The Chechen-Ingush were sent to internal exile in so-called special settlements (spetsposelenia). These were villages located in resource-rich but inhospitable areas in Central Asia that were built in the 1930s by exiled peasants. Deportees were territorially dispersed. The Kazakhstan oblast' of Akmola, for example, received about 60,000 deportees, but their number in local communities never exceeded more than a few dozen families. This territorial dispersion of deportees prevented them from effective communication and internal organization. ${ }^{82}$ In the special settlements, the Chechens were officially forbidden to express their culture. Chechen art, folklore, music, and history were suppressed, and important Chechen national figures were purged from the Great Soviet Encyclopaedia. ${ }^{83}$ In theory, the special settlements were seen to function as a mechanism for the re-education of anti-Soviet elements. This practice, it seems, remained superficial in practice.$^{84}$ A policy of linguistic Russification of these peoples was pursued, but hardly successfully so. In 1926, 99,7\% of Chechen-Ingush spoke their native language, and by 1959 the number had dropped a mere one percent to $98,7 \%{ }^{85}$

Forced assimilation can be defined as the pursuit of compulsive policies aimed at an ethnically defined group of people, which leads to the involuntary adoption of the dominant identity or ethnicity of the state. ${ }^{86}$ With regard to this practice, it can be argued that the very act of removal and resettlement was, at least partly, an attempt to achieve assimilation. It can also be argued that frustrations with earlier failed attempts of forced assimilation and

\footnotetext{
${ }^{76}$ Boztas, Did a Genocide Take Place?

${ }_{77}$ Pohl, Ethnic Cleansing in the USSR, 9, 84.

${ }^{78}$ Amir Weiner, "Saving Private Ivan: From What, Why, and How?" Kritika: Explorations in Russian and Eurasian History 1, no. 2 (2008), 332; Polian, Against Their Will, 147; Naimark, Fires of Hatred, 97.

${ }^{79}$ Pohl, Stalin's Genocide against the 'Repressed Peoples', 284.

${ }^{80}$ Morland, Demographic Engineering, 34; Bookman, The Demographic Struggle for Power, 121-146.

${ }^{81}$ Zeydanlığlu, The White Turkish Man's Burden, 10.

${ }^{82}$ Michaela Pohl, “'It Cannot Be That Our Graves Will Be Here': The Survival of Chechen and Ingush Deportees in Kazakhstan, 1944-1957," Journal of Genocide Research 4, no. 3 (2002), 403-404.

${ }^{83}$ Francine Hirsch, "Race without the Practice of Racial Politics," Slavic Review 61, no. 1 (2002), 40.

${ }^{84}$ See Lynne Viola, "Stalin's Empire: The Gulag and Police Colonization in the Soviet Union in the 1930s," in Stalin and Europe: Imitation and Domination, 1928-1953, ed. Timothy Snyder and Ray Brandon (New York: Oxford University Press, 2014), 18-44, for a concise discussion of the Gulag and special settlement system.

${ }^{85}$ Gerhard Simon, Nationalism and Policy toward the Nationalities in the Soviet Union: From Totalitarian Dictatorship to Post-Stalinist Society (Boulder: Westview Press, 1991), 395-396.

${ }^{86}$ Bookman, The Demographic Struggle for Power, 105.
} 
incorporation played an important role in the motivation for both operations. In this regard, it is important to distinguish between the direct trigger for deportation - perceived collaboration in the case of the Chechen-Ingush, and rebellion in the case of the Zaza Kurds - and deeper underlying processes of attempted incorporation of these groups that played an indirect albeit fundamental role.

Concerning the settlement of these peoples, the Chechen-Ingush and Zaza Kurds were settled in areas where they could more easily be monitored and controlled by the state. In Dersim, this happened within the region itself as well, where people were removed from a difficult to access forbidden zone and settled in the less isolated periphery of the region.

\section{Discussion}

The high degree of practical similarities in the two case studies presented above raises important questions about the causal mechanisms underlying the application of forced internal population movements as a method of statecraft. Scholars of demographic engineering often understand forced (internal) population settlements as being driven by schemes aimed at the enhancement of the demographic dominance of a certain ethnic group in a particular geographic area through the removal of minority groups. ${ }^{87}$ Yet, the forced settlement of the Chechen-Ingush and the Zaza Kurds does not seem to have been driven by desires of unmixing populations, but rather by a desire to establish control over the unruly population groups themselves through settling them in more easily controllable areas. It was no coincidence that both Dersim and Chechen-Ingushetia were inhospitable and isolated rural regions. In the perverted logic of these regimes, forced population settlement was a viable political strategy to incorporate these areas in the political order, as well as the people inhabiting them. This observation suggests that not only ethnic identity, but geography as well can be an important factor in demographic engineering.

Of further importance is that both instances of mass violence were framed and legitimized as collective punishment operations against peoples resisting the newly installed political order and unwilling to give up their so-called backward identity. Despite the extensive use of violence and ample instances of cruelty, these were operations of resettlement as much as of removal. The Soviets and Kemalists both possessed the operational capacity to murder the entirety of these population groups, but they did not do so. It was the cultural identity of these groups that had to be eradicated from the face of the earth, not the people as physical beings. This can be accounted for by the absence of a motivation of biological racism and by the primacy of nurturist thought. These observations could serve to open up the discussion about how these two cases relate to cases of (cultural) genocide, and to what extent these cases themselves should be considered as such. ${ }^{88}$ Such a discussion, not within the scope of this article, could focus on the way ethnic diversity is portrayed in relation to the political goals of the regime in order to understand alternating tendencies of incorporation and assimilation as well as their relation to practices of demographic engineering, population resettlement and, potentially, to genocide.

Future research could benefit from the framework and analytic insights provided by this article and help to provide a more detailed understanding of the similarities and differences of these regimes and of their policies. One of the implications of this study has been to underline the importance of regime change in order to understand violent population policies towards ethnic minorities. Hence, a possibility for further research would be to extend the comparison to include other states that experienced regime changes and in which ethnic minority groups made up a significant part of the population, such as post-colonial India or Communist China. How did these new states represent ethnic diversity? To what extent was resettlement of population groups practiced by these states, and with which goals? Were notions of backwardness used to refer to the predicament of the country as a whole, or to particular regions of it, in these cases as well? And how did this relate to the treatment of ethnic minority groups? Additionally, research with primary

${ }^{87}$ Ibid, 121; Morland, Demographic Engineering, 39; Myron Weiner and Michael Teitelbaum, Political Demography, Demographic Engineering (New York: Berghahn Books, 2001), 55, 65-74.

${ }^{88}$ See Boztas, Did a Genocide Take Place?; Norman M. Naimark, Stalin's Genocides (Princeton: Princeton University Press, 2010) for separate discussions of these two cases as genocide. 
source material in Turkish and Russian could offer a more comprehensive and varied picture of understandings of nationality in both states, as well as of internal discussions on nurturism. Primary source material could further give enhanced insight into the fate of the Chechen-Ingush and the Zaza Kurds in internal exile. Finally, it would be an important contribution to analyze the way the memory of state violence from the perspective of the persecuted groups has played a role in recent conflicts between the Russian and Turkish states and Chechen and Kurdish minorities. Such research could yield insight into how policies aimed at the forceful incorporation of these ethnic groups have had the long-term effect of creating new enmities that continue leading to conflict to this very day.

\section{Acknowledgements}

This article is an abridged version of the master's thesis I wrote at Utrecht University. The full version is available upon request. My sincere gratitude goes to Dr. Uğur Ümit Üngör for his supervision during the writing of my master's thesis and this article.

\section{Bibliography}

Akçam, Taner. The Young Turks' Crime against Humanity: The Armenian Genocide and Ethnic Cleansing in the Ottoman Empire. Princeton, New Jersey: Princeton University Press, 2012.

Alemdaroğlu, Ayça. "Politics of the Body and Eugenic Discourse in Early Republican Turkey." Body \& Society 11, no. 3 (2005): 61-76. https://doi.org/10.1177/1357034X05056191

Bauman, Zygmunt. Modernity and the Holocaust. Ithaca, New York: Cornell University Press, 1991.

Bookman, Milica Zarkovic. The Demographic Struggle for Power: The Political Economy of Demographic Engineering in the Modern World. London: Routledge, 2013.

Boztas, Özgür Inan. “Did a Genocide Take Place in the Dersim Region of Turkey in 1938?" Papers of the Strassler Center for Holocaust and Genocide Studies, 2015: 1-20.

Cagaptay, Soner. Islam, Secularism and Nationalism in Modern Turkey: Who Is a Turk?. Abingdon: Routledge, 2006.

Cheng, Yinghong. Creating the "New Man": From Enlightenment Ideals to Socialist Realities. Honolulu: University of Hawaii Press, 2009.

Demeny, Paul. "Population Policy: The Role of National Governments." Population and Development Review 1, no. 1 (1975): 147-161. https://doi.org/10.2307/1972274

Eisenstadt, Shmuel. "The Kemalist Revolution in Comparative Perspective." In Atatürk, Founder of a Modern State, edited by Ergun Özbudun and Ali Kazancigil, 127-40. London: C. Hurst, 1981.

Fitzpatrick, Sheila. "How the Mice Buried the Cat: Scenes from the Great Purges of 1937 in the Russian Provinces." The Russian Review 52, no. 3 (1993): 299-320. https://doi.org/10.2307/130732

Foucault, Michel. "Governmentality." In The Foucault Effect: Studies in Governmentality, edited by Graham Burchell, Colin Gordon, and Peter Miller, 87-104. Chicago: The University of Chicago Press, 1991.

Getty, J. Arch, and Oleg V. Naumov. The Road to Terror: Stalin and the Self-Destruction of the Bolsheviks, 1932-39. Annals of Communism. New Haven: Yale University Press, 2000.

Geyer, Michael, and Sheila Fitzpatrick, eds. Beyond Totalitarianism: Stalinism and Nazism Compared. New York: Cambridge University Press, 2009.

Gingeras, Ryan. Fall of the Sultanate: The Great War and the End of the Ottoman Empire, 1908-1922. Oxford: Oxford University Press, 2016. https://doi.org/10.1093/acprof:oso/9780199676071.001.0001

Gökalp, Ziya. The Principles of Turkism. Translated and annotated by Robert Devereux. The Netherlands: Leiden E.J. Brill, 1968.

Gorlizki, Yoram, and Hans Mommsen. "The Political (Dis)Orders of Stalinism and National Socialism." In Beyond Totalitarianism: Stalinism and Nazism Compared, edited by Michael Geyer and Sheila Fitzpatrick, 41-86. New York: Cambridge University Press, 2009.

Hanioğlu, M. Şükrü. Atatürk: An Intellectual Biography. Princeton: Princeton University Press, 2011. https://doi.org/10.1515/9781400838172

Hirsch, Francine. Empire of Nations: Ethnographic Knowledge \& the Making of the Soviet Union. Ithaca: Cornell University Press, 2005. 
--------. "Race without the Practice of Racial Politics." Slavic Review 61, no. 1 (2002): 30-43. https://doi.org/10.2307/2696979

Hirschon, Renee. Crossing the Aegean: An Appraisal of the 1923 Compulsory Population Exchange between Greece and Turkey. New York: Berghahn Books, 2003. https://doi.org/10.2307/j.ctt1x76f3x

Hoffmann, David. Cultivating the Masses: Modern State Practices and Soviet Socialism, 1914-1939. Ithaca: Cornell University Press, 2011. https://doi.org/10.7591/cornell/9780801446290.001.0001

Hoffmann, David and Yanni Kotsonis, eds. Russian Modernity: Politics, Knowledge, Practices. New York: St. Martin's Press, 2000. https://doi.org/10.1057/9780230288126

Holquist, Peter. "State Violence as Technique: The Logic of Violence in Soviet Totalitarianism." In Stalinism: The Essential Readings, edited by David L. Hoffmann, 129-156. Oxford: Blackwell Publishers, Ltd., 2003. https://doi.org/10.1002/9780470758380.ch6

. "To Count, to Extract, and to Exterminate: Population Statistics and Population Politics in Late Imperial and Soviet Russia." In A State of Nations: Empire and Nation-Making in the Age of Lenin and Stalin, edited by Ronald Grigor Suny and Terry Martin, 111-144. New York: Oxford University Press, 2001.

Khalid, Adeeb. "Backwardness and the Quest for Civilization: Early Soviet Central Asia in Comparative Perspective." Slavic Review 65, no. 2 (2006): 231-251. https://doi. org/10.2307/4148591

-. "Nationalizing the Revolution in Central Asia: The Transformation of Jadidism, 19171920." In State of Nations: Empire and Nation-Making in the Age of Lenin and Stalin, edited by Ronald Grigor Suny and Terry Martin, 145-164. New York: Oxford University Press, 2001.

Kieser, Hans-Lukas. “Dersim Massacre, 1937-1938." Online Encyclopedia of Mass Violence. July 27, 2011. Accessed May 24, 2017. http://www.sciencespo.fr/mass-violence-war-massacreresistance/en/document/dersim-massacre-1937-1938.

Kotkin, Stephen. "Modern Times: The Soviet Union and the Interwar Conjuncture." Kritika: Explorations in Russian and Eurasian History 2, no. 1 (2008): 111-164. https://doi.org/10.1353/ $\underline{\text { kri.2008.0119 }}$

Krementsov, Nikolai. "From 'Beastly Philosophy' to Medical Genetics: Eugenics in Russia and the Soviet Union." Annals of Science 68, no. 1 (2011): 61-92. https://doi.org/10.1080/00033790.2 $\underline{010.527162}$

Ladas, Stephen Pericles. The Exchange of Minorities: Bulgaria, Greece and Turkey. New York: MacMillan, 1932.

Levene, Mark. Crisis of Genocide: The European Rimlands 1912-1938. Oxford: Oxford University Press, 2014.

Lohr, Eric. Nationalizing the Russian Empire: The Campaign against Enemy Aliens during World War I. Cambridge, MA: Harvard University Press, 2003.

"The Russian Army and the Jews: Mass Deportation, Hostages, and Violence during World War I." The Russian Review 60, no. 3 (2001): 404-419. https://doi.org/10.1111/0036-0341.00177

Mann, Michael. The Dark Side of Democracy: Explaining Ethnic Cleansing. New York: Cambridge University Press, 2005.

Martin, Terry. The Affirmative Action Empire: Nations and Nationalism in the Soviet Union, 1923-1939. Ithaca: Cornell University Press, 2001.

McDowall, David. A Modern History of the Kurds. 3rd ed. London: I.B. Tauris, 2004.

Morland, Paul. Demographic Engineering: Population Strategies in Ethnic Conflict. International Population Studies. Farnham: Routledge, 2014.

Naimark, Norman M. Fires of Hatred: Ethnic Cleansing in Twentieth-Century Europe. London: Harvard University Press, 2001.

-------. Stalin's Genocides. Princeton: Princeton University Press, 2010.

Northrop, Douglas. "Nationalizing Backwardness: Gender, Empire, and Uzbek Identity." In State of Nations: Empire and Nation-Making in the Age of Lenin and Stalin, edited by Ronald Grigor Suny and Terry Martin, 191-220. New York: Oxford University Press, 2001.

Plaggenborg, Stefan. Ordnung Und Gewalt: Kemalismus - Faschismus - Sozialismus. München: Oldenbourg, 2012. https://doi.org/10.1524/9783486714098 
Pobol, N.L and Polian, P., eds. Stalinskie Deportacii, 1928-1953, Čast' 3. Etničeskie Deportacii Periodia Velikoj Otečestvennoj Vojny (22 ijunja 1941- 9 maja 1945). Moscow: The Yakovlev Foundation, 2005. Documents 3.115, 3.116, 3.121,3.124. Accessed May 24, 2017. http:// www.alexanderyakovlev.org/fond/issues/parts/62150/1022098.

Pohl, J. Otto. Ethnic Cleansing in the USSR, 1937-1949. Westport, CT: Greenwood Press, 1999.

-------. "Stalin's Genocide against the 'Repressed Peoples."' Journal of Genocide Research 2, no. 2 (2000): 267-293. https://doi.org/10.1080/713677598

Pohl, Michaela. "'It Cannot Be That Our Graves Will Be Here': The Survival of Chechen and Ingush Deportees in Kazakhstan, 1944-1957." Journal of Genocide Research 4, no. 3 (2002): 401-430. https://doi.org/10.1080/14623520220151989

Polian, Pavel. Against Their Will: The History and Geography of Forced Migrations in the USSR. Budapest: Central European University Press, 2004.

Quine, Maria Sophia. Population Politics in Twentieth-Century Europe: Fascist Dictatorships and Liberal Democracies. New York: Routledge, 1996. https://doi.org/10.4324/9780203410592

Şeker, Nesim. "Demographic Engineering in the Late Ottoman Empire and the Armenians." Middle Eastern Studies 43, no. 3 (2007): 461-474. https://doi.org/10.1080/00263200701246157

Simon, Gerhard. Nationalism and Policy toward the Nationalities in the Soviet Union: From Totalitarian Dictatorship to Post-Stalinist Society. Boulder: Westview Press, 1991.

Slezkine, Yuri. "The USSR as a Communal Apartment, or How a Socialist State Promoted Ethnic Particularism." In Stalinism: New Directions. London: Routledge, 2000.

Stalin, Joseph. "Marxism and the National Question (1913)." In Marxism and the National and Colonial Question, a Collection of Articles and Speeches. Translated by A. Fineberg, 3-61. Moscow: Partizdat, 1934.

. "The October Revolution and the National Policy of the Russian Communists (1921)." In Marxism and the National and Colonial Question, a Collection of Articles and Speeches. Translated by A. Fineberg, 117-119. Moscow: Partizdat, 1934.

-------. "Theses on the Immediate Tasks of the Party in Connection with the National Problem, Presented to the Tenth Congress of the R.C.P., Endorsed by the Central Comittee." In Marxism and the National and Colonial Question, a Collection of Articles and Speeches. Translated by A. Fineberg, 88-98. Moscow: Partizdat, 1934.

Steinberg, Mark. "Russia's Fin Die Siècle, 1900-1914." In The Cambridge History of Russia. Vol. 3, The Twentieth Century, edited by Ronald Grigor Suny, 65-93. Cambridge, UK: Cambridge University Press, 2008.

Suny, Ronald Grigor. "They Can Live in the Desert but Nowhere Else": A History of the Armenian Genocide. Princeton: Princeton University Press, 2015.

Suny, Ronald Grigor and Terry Martin, eds. State of Nations: Empire and Nation-Making in the Age of Lenin and Stalin. New York: Oxford University Press, 2001.

Ülker, Erol. "Assimilation, Security and Geographical Nationalization in Interwar Turkey: The Settlement Law of 1934." European Journal of Turkish Studies. Social Sciences on Contemporary Turkey, no. 7 (2008): 1-19.

Üngör, Uğur Ümit. "Seeing like a Nation-State: Young Turk Social Engineering in Eastern Turkey, 1913-50." Journal of Genocide Research 10, no. 1 (2008): 15-39. https://doi. org/10.1080/14623520701850278

. "State Violence under Kemalism and Stalinism: Common Themes and Analogies." Unpublished article, 2017: 1-15.

. The Making of Modern Turkey: Nation and State in Eastern Anatolia, 1913-1950. Oxford: Oxford University Press, 2012.

Viola, Lynne. Peasant Rebels under Stalin: Collectivization and the Culture of Peasant Resistance. New York: Oxford University Press, 1996.

. "Stalin's Empire: The Gulag and Police Colonization in the Soviet Union in the 1930s." In Stalin and Europe: Imitation and Domination, 1928-1953, edited by Timothy Snyder and Ray Brandon, 18-44. New York: Oxford University Press, 2014. https://doi.org/10.1093/ acprof:0so/9780199945566.001.0001 
Watts, Nicole. "Relocating Dersim: Turkish State-Building and Kurdish Resistance, 1931-1938." New Perspectives on Turkey 23 (2000): 5-30. https://doi.org/10.1017/S0896634600003368

Weiner, Amir. "Introduction: Landscaping the Human Garden." In Landscaping the Human Garden: Twentieth-Century Population Management in a Comparative Framework. Stanford: Stanford University Press, 2003. https://doi.org/10.1201/9780203912676.pt1

--------. "Nature, Nurture, and Memory in a Socialist Utopia: Delineating the Soviet Socio-Ethnic Body in the Age of Socialism." The American Historical Review 104, no. 4 (1999): 1114-1155. https://doi.org/10.2307/2649563

------. "Saving Private Ivan: From What, Why, and How?" Kritika: Explorations in Russian and Eurasian History 1, no. 2 (2008): 305-336.

Weiner, Myron, and Michael Teitelbaum. Political Demography, Demographic Engineering. New York: Berghahn Books, 2001.

Weitz, Eric D. A Century of Genocide: Utopias of Race and Nation. Princeton: Princeton University Press, 2015. https://doi.org/10.1515/9781400866229

---------. "Racial Politics without the Concept of Race: Reevaluating Soviet Ethnic and National Purges." Slavic Review 61, no. 1 (2002): 1-29. https://doi.org/10.2307/2696978

--------. "Utopian Ideologies as Motives for Genocide." In Encyclopedia for Genocide and Crimes Against Humanity, edited by Dinah L. Shelton, 1124-1127. World History in Context. Detroit: Thomson/Gale, 2005.

Yegen, Mesut. "'Prospective-Turks' or 'Pseudo-Citizens:' Kurds in Turkey." The Middle East Journal 63, no. 4 (2009): 597-615. https://doi.org/10.3751/63.4.14

Zeydanlığlu, Welat. "'The White Turkish Man's Burden': Orientalism, Kemalism and the Kurds in Turkey." In Neo-Colonial Mentalities in Contemporary Europe? Language and Discourse in the Construction of Identities, edited by Guido Rings and Anne Ife, 1-17. Newcastle upon Tyne: Cambridge Scholars Publishing, 2008.

Zürcher, Erik Jan. "Institution Building in the Kemalist Republic: The Role of the People's Party." In Men of Order: Authoritarian Modernisation in Turkey and Iran, 1918-1942, edited by Erik Jan Zürcher and Touraj Atabaki, 98-112. London: I.B.Tauris, 2004.

-------. Turkey: A Modern History. New York: I.B. Tauris, 2004.

Zürcher, Erik Jan and Touraj Atabaki. "Introduction." In Men of Order: Authoritarian Modernisation in Turkey and Iran, 1918-1942, 1-12. London: I.B.Tauris, 2004. 